\title{
PENDIDIKAN INTEGRAL KEILMUAN KEAGAMAAN DAN KONTEKS SOSIAL KEBUDAYAAN DALAM MENJAWAB ISU-ISU KONTEMPORER
}

\author{
M. Alie Humaedi \\ Peneliti Kajian Budaya \\ Pusat Penelitian Kemasyarakatan dan Kebudayaan LIPI
}

\begin{abstract}
Hundreds of Islamic higher education has been developing in Indonesia. Despite its existence, the struggle may not yet be considered significant compared to public universities. On the other hand, Indonesia has a high level of multiculturalism and major religious communities which can trigger a better product of Islamic higher education. This fact shows that prominent problems still rise both in the structure and paradigm of the distinct teaching, also in the level of how scholar responses in contemporary issues. The blame can be taken to the reality that the learning paradigm and structure are still providing limitation in specific religious knowledge. In order to establish an Islamic higher education to be called the center of learning and research as an agent of civilization development, the religious and integral social culture education must be capable in determining the cultural context and geo-history of the people which affects both the internality of a religion and the daily practices.
\end{abstract}

Keyword: Islamic higher education, integral education, socio-cultural, agent of development.

\section{Abstrak}

Puluhan bahkan ratusan pendidikan tinggi agama Islam telah ada di Indonesia. Bila dibandingkan dengan pendidikan tinggi umum, kiprahnya pun masih belum terlihat banyak. Padahal, di tengah tingkat keberagamaan dan jumlah pemeluk agama yang besar, tentu keberadaan dan perannya bisa lebih dari apa yang terlihat sekarang. Artinya, ada masalah krusial, baik dalam struktur dan paradigma keilmuan yang diajarkan, maupun tingkat pemahaman para sivitas dalam menjawab isu-isu kontemporer. Ujung pangkalnya tetap satu, yaitu struktur dan paradigma keilmuan yang masih sebatas pengkajian spesifik ilmu-ilmu agama saja. Pendidikan integral ilmu agama dan keilmuan sosial kebudayaan yang bisa membaca dan mengangkat konteks kultur dan geo-historis masyarakat, yang berpengaruh dalam internalisasi keagamaannya ataupun praktik kehidupan pelaku, sangat penting untuk dirumuskan dan ditetapkan sebagai bagian tidak terpisah mencipta pendidikan tinggi agama Islam yang menjadi center of learning and research, sekaligus agen perubahan di masyarakat

Kata kunci: perguruan tinggi agama, pendidikan integral, sosial kebudayaan, agen perubahan

\section{PENDAHULUAN}

Muhamad Iqbal dalam syairnya mengungkapkan harapannya untuk bisa mendapatkan opium merah hingga mampu mencari tiang gantung dirinya. ${ }^{1}$ Kemabukan bukanlah penghancur. Ia adalah refleksi kesadaran. Apa makna terdalam dari syair Iqbal bila dikaitkan

1 Muhammad Iqbal. 1987. Javid Namah: Kitab Keabadian, Jakarta, Pustaka Panjimas, h. 48 
dengan persoalan memajukan keilmuan di perguruan tinggi Islam? Kata mabuk dalam konteks kalimat Iqbal, bukanlah mabuk dalam arti sejatinya yang disebabkan oleh pengaruh obat atau minuman. Mabuk dalam pemikiran Iqbal tidak akan dilepaskan dari pemikirannya yang holistik dan tercerabut dari akar tradisi keagamaannya. Secara universal, Iqbal berkehendak mengakomodasi peradaban Timur yang dipenuhi dengan hati atau cita rasa kebudayaan dan peradaban Barat yang mengedepankan logika atau akal piker yang masing-masing mempengaruhi kajian dalam aspek-aspek keduniawian dan keakhiratan. Akomodasi kedua peradaban itulah yang membuat dirinya selalu berada pada posisi limbung, walaupun ia tetap berkehendak menetapkan keputusan dan pertimbangan pemikirannya secara kuat.

Kutipan syair Muhamad Iqbal sengaja dilakukan untuk menanyakan kembali sistem pendidikan Islam yang ada pada UIN/IAIN/ STAIN atau PTAI lainnya selama hampir empat puluhan tahun sejak berdirinya, yang dianggap masih kurang maksimal memberikan jawaban bagi isu-isu kontemporer, terutama pada aspek-aspek sains, moralitas, teknologi, ataupun keagamaan itu sendiri. Terlebih ketika desakan dan pengaruh globalisasi, buah dari era milenium ketiga, tersebut semakin kuat menekan semua elemen kehidupan. Padahal tidak semua perguruan tinggi Islam itu telah memasukkan ruh globalisasi pada dunia pengajarannya, bahkan ada di antaranya masih menganggap hal tersebut sebagai suatu "kegaiban" yang tidak perlu dipikirkan secara mendalam. Fenomena globalisasi di berbagai bidang kehidupan seperti itu merupakan tantangan baru yang harus dihadapi manusia di masa kini dan mendatang, bukan sebaliknya untuk dihindari.

Meskipun disadari bahwa pengembangan pendidikan di perguruan tinggi Islam tetap berjalan pada suatu visi humanitas dan pendekatan yang berpusat pada nilai asas Qur'an dan Hadits (seperti pandangan Amin
Abdullah yang digambarkan dalam diagram horizon ilmu), ${ }^{2}$ tetapi dalam prosesnya ada nilai-nilai yang perlu memperhatikan empat wilayah keprihatinan. Pertama sikap yang realistis dan seimbang dalam menghadapi proses kompleks globalisasi agama, budaya dan masyarakat; kedua, digunakannya kerangka epistemologis yang holistik dan berwawasan ekologis; ketiga pembedaan antara unsur-unsur lokal dan universal, serta interplay di antara keduanya; dan keempat, dilibatkannya nilai-nilai spiritual yang berasal dari sumber-sumber yang transenden. Jika Amin Abdullah hanya berpusat pada nilai keempat (Qur'an dan Hadits), maka perlulah dipikirkan kembali adanya tiga nilai lain yang tidak kalah urgennya, meskipun mungkin dari sudut pandang "seorang ilmuwan dan agamawan dari UIN/IAIN/STAIN" ketiga nilai itu telah tercover dalam nilai terakhir tersebut, sebagaimana umumnya pandangan tentang nilai-nilai profetik. ${ }^{3}$

Jika tiga nilai, selain nilai transenden diatas diajukan, maka tuntutan mendasar dalam penerapan dan pengembangan pendidikan kajian-kajian kontemporer adalah upaya memberdayakan, merekayasa, dan mendayagunakan ilmu-ilmu bantu dalam interaksinya dengan nilai yang terakhir. Ilmuilmu bantu, seperti antropologi, kajian budaya, sosiologi, sejarah, psikologi, ekologi dan lainnya perlu mendapatkan tempat strategis dalam proses pembelajaran pendidikan Islam. Namun, ilmu bantu itu tidak serta merta diajarkan sebagaimana umumnya proses pembelajaran

${ }^{2}$ M. Amin Abdullah, "Pengembangan Kajian KeIslaman: Metode dan Pendekatannya Pada Program Pascasarjana UIN/IAIN/STAIN" makalah yang disampaikan pada semiloka Pengembangan Program Pascasarjana IAIN di Padang tanggal 26-28 Desember 2002, dan diulanginya pada kesempatan Seminar Internasional Pemikiran Abdullah Ahmad an-Naem, di Radisson Hotel Yogyakarta pada tanggal 8 Januari 2003. pemikiran ini pula termuat pada tulisannya "Kajian Ilmu Kalam di IAIN: Menyongsong Perguliran Paradigma Keilmuan Keislaman pada Era Milenium Ketiga" dalam alJamiah, No. 65/VI/2000.

3 Kuntowijoyo. 1997. Muslim Tanpa Masjid. Yogyakarta, LkiS, 1997. h. 30-67. 
di tempat lain, tetapi ia harus mendapatkan sentuhan berbeda karena perpaduannya dengan aspek-aspek keagamaan. Oleh karena itu, diperlukan suatu kemampuan antisipasi atau dalam bahasa Jurgen Habermas dilakukan tindakan komunikasional ${ }^{4}$ yang melihat juga aspek-aspek dalam liminalitas kesejarahan fakta ${ }^{5}$ seperti nilai transendensi, asbabun nuzul, asbabul wurud, dirayah hadits, dan jaringan keilmuan. Hal ini dilakukan untuk menangani konsekuensi-konsekuensi yang tidak diinginkan, seperti pengacauan subject matter keilmuan agama yang diajarkan. Tindakan komunikasional juga tetap dibutuhkan para sivitas sebagai langkah untuk menyesuaikan diri dari perubahan yang ditawarkan globalisme, sehingga tidak akan keluar dari jalur-jalur interaksi individu dan sosialnya yang ada. Proses dari tindakan komunikasional tersebut membutuhkan materi pendidikan yang tepat dan fasilitas media ideologi ${ }^{6}$ yang berbekal pada pemahaman dan appropriasi ${ }^{7}$ atas fenomena globalisasi tersebut.

\section{Dikotomi Ilmu dan Konteks yang Membahayakan}

Pengembangan ilmu yang islami selalu diidentikkan secara langsung dengan adanya dikotomi ilmu pengetahuan dan teknologi yang sekuler, dan terpisah dari ilmu keagamaan. Dualisme ini rupanya memberi dampak pada keputusan politik, wawasan budaya, filsafat, kriteria kebenaran, dan kehidupan sosial, dan juga kepribadian seseorang dari para sivitas ilmu pengetahuan. Walau disadari bahwa dewasa ini UIN/IAIN/STAIN telah melakukan suatu usaha untuk memberikan kesatuan yang

${ }^{4}$ Juergen Habermas. 1979. Communication and the Evolution of Society. Boston, Beacon Press. h. 21

${ }^{5}$ Anthony Giddens. 1976. New Rules of Sociological Method, (New York: Basic Books. h. 89

${ }^{6}$ Talcott Parson. 1951. The Social System, (Glencoe: The Free Press. h. 11

${ }^{7}$ Paul Ricouer. 1991. From Text to Action: Essay in Hermeneutics II, (Evanston Illinois: Northwestern University Press. h. 2 utuh komprehensif terhadap dualisme yang terjadi.

Disebut-sebut ilmu pengetahuan yang sekuler antroposentris selalu dan telah mengagungkan ke-"aku-an manusia dan ini semuanya terlihat pada ketiga nilai di atas. Sementara itu, nilai keempat akan selalu menunjuk tentang kekuasaan Tuhan yang mengetahui semua yang gaib dan nyata, serta akan membanggakan diri bahwa al-Qur'an sebagai sumber segala ilmu. Esensi yang dimaksud adalah tauhid yang merupakan spiritualitas tertinggi ilmu pengetahuan. Perdebatan ini akan terus berlangsung jika terjadi pendikotomian yang tiada henti. Tulisan ini tidak ingin mendebatkan sesuatu yang selalu bersifat "sempit", karena pendikotomian tersebut merupakan sikap picik sivitas Islam yang selalu mengagungkan "tanpa kacamata lain" ilmu yang dianggapnya selalu bersumber pada al-Qur'an. Padahal ayatayat al-Qur'an hanyalah teks tulis tertutup yang dibuat dan dibatasi dalam konsep ruang dan waktu, dan untuk mengkajinya ia memerlukan intertekstualitas dari ayat-ayat yang terbuka (seperti tercermin pada nilai ketiga, yaitu adanya hubungan dengan ekologi) yang selalu berubah dan menuntut terjadinya inovasi baru yang kreatif dan dinamis.

Teks tulis hanyalah rujukan yang tidak dapat dijadikan pemecahan, karena itulah al-Qur'an bersifat universal. Keautentikan al-Qur'an adalah usaha mengkaji intertektualitasnya dengan teks alam (kauniyah) dan tidak memberikan jawaban atas tantangan globalisasi secara tertulis, melainkan kesan sosiolinguistik al-Qur'an yang mampu mengcovernya. Kesan bawah sadar teks inilah yang hanya mampu ditemukan dengan pengembangan ilmu pengetahuan rasional dan teknologi empirik serta teknologi budaya yang harus terus digali oleh manusia.

Makna bawah sadar bukan sesuatu yang menjadi tumpuan harapan problems solving kehidupan, tetapi ia sekedar nilai yang mampu memberikan dampak refleksi kesadaran 
manusiadalamberpikirdaninovasinya. Artinya, kebebasan manusia berinovasi teknologi selalu berlandaskan pada nilai tersebut, dan di sinilah fungsinya al-Qur'an dan tradisi agama lainnya. Pengkajian keagamaan dalam sudut pandang ini sebenarnya berpusat pada "keberagamaan" atau menemukan "makna agama". Maka segala ilmu yang dikaji berhubungan dengan agama harus diletakkan pada dasar keberagamaan sebagai hasil dan tujuan pokoknya. Sementara ilmu-ilmu yang mengantarkan ke arah sana merupakan sarana atau fasilitas sekunder. Intinya bukan pada Qur'an dan tradisinya, melainkan universalitas keberagamaan. Dipastikan ilmu yang mengantarkan kepada universalitas keberagamaan tersebut akan melahirkan ideologi-ideologi (ilmu sebagai ideologi Habermas) ${ }^{8}$ yang memberi kuasa terhadap interpretasi keberagamaannya sesuai epistemologis dan ontologis dari obyek material dan obyek formal ilmunya.

Wajarlah jika dalam perkembangannya akan melahirkan "kebenaran-kebenaran" atau dalam bahasa tasawuf sering disebut sebagai "ana al-haq" terhadap spiritualitasnya. Banyaknya "ana al-haq" bukanlah dianggap suatu kesalahan tetapi ia merupakan kreasi positif dari kesadaran manusia dalam merefleksikan keberagamaannya. Akomodasi antar al-haq itulah yang harus dicover dan dijadikan landasan teleologis strategis pengembangan keilmuan Islam di perguruan tinggi agama. Identitas "Ana al haq" ilmu itu bisa bersifat sosiologis yang positivistik empirik, antropologi yang culture materialisme, ${ }^{9}$ bisa ekonomi yang kapitalisme etatisme, bisa politik yang demokratis liberalisme, bisa filologi yang naratif, bisa arkeologi yang publik, bisa fenomenologi yang verstehen dan heuristik, bisa syariah yang fiqh, bisa tafsir yang hermeneutik, tahlili ataupun maudui, bisa kalam

${ }^{8}$ Juergen Habermas. 1971. Knowledge and Human Interest. Boston: Beacon Press. h. 71

${ }^{9}$ Andrew P. Vayda dan Roy A. Rappaport. .1968. "Ecology: Cultural and NonCultural" dalam James H. Clifton, ed. Introduction to Cultural Anthropology. Boston, Houghton Mifflin), h. 477-497 yang deterministic, bisa filsafat yang perenial, dan sebagainya. Spiritualitas dari identitas "ana al haq" ilmu inilah yang merupakan respon positif yang harus dikembangkan secara terus menerus dan diberi dorongan plus untuk pemberdayaannya.

Jika demikian, maka perguruan tinggi agama seperti UIN/IAIN/STAIN sebenarnya mempunyai posisi strategis untuk mampu memberi ruang terjadinya perjumpaan antar berbagai identitas "ana al-haq" tersebut, berbeda dengan perguruan tinggi lainnya yang kurang memiliki kapasitas itu. Artinya pengkajian ilmu di perguruan agama tidak sebatas "ana al-haq" pada ilmu yang mengantarkan keberagamaan dengan sudut pandang objek material dan formal keagamaan belaka, tetapi juga terjadinya transfer dan pengkajian dalam horizon "ana al-haq" yang bersifat menduniawi hingga terjadi pertemuan ana al-haq transenden dengan spiritualitas kontekstual yang melahirkan jawab dan respon terhadap berbagai permasalahan yang ada. Terjadinya agamawan yang scientis teknokratis dan scientis teknokrat yang agamis bukan sekedar pembayangan, tetapi suatu idealisasi yang diharapkan. Ia bukan pula ilusi tetapi menjadi ideologi ilmu yang komunikatif.

Idealisasi di atas menuntut adanya penyamarataan obyek-obyek materi ilmu, tidak ada pembedaan pada level pertama, level kedua, level ketiga dan seterusnya karena semuanya hanya alat pengantar mencapai "keberagamaan itu sendiri". Maka tiadalah istilah ilmu pokok, yang meliputi ilmu-ilmu agama, seperti fiqh, ushul fiqh, tafsir, kalam dan sebagainya, dan ilmu-ilmu bantu, seperti antropologi, sosiologi, psikologi, filologi, arkheologi dan sebagainya. Landasan yang mencirikan pengkajian ilmu di perguruan tinggi agama adalah kemampuannya untuk memberikan ruang pertemuan dari berbagai ilmu tersebut hingga mendapatkan universalitas kebenaran. Selanjutnya bukan pada perihal terjadinya islamisasi ilmu 
pengetahuan dan teknologi tetapi memberikan nilai plus ilmu dengan keberagamaan.

\section{Landasan Pengembangan Pendidikan Integral}

Persoalan penting yang selalu mengusik pengembangan keilmuan pada suatu lembaga pendidikan agama pastilah dibenturkan pada bagaimana Islam sebagai warisan keagamaan, budaya, politik dan etika berhadapan dengan dunia modern dan dunia yang cepat berubah. Pada satu sisi, modernitas dianggap sebagai fenomena wajah Janus (dewa Romawi yang berwajah ganda yang mampu melihat dua arah yang berlawanan). Ia tentu saja membawa ilmu pengetahuan dan teknologi yang bemanfaat bagi masyarakat Muslim, tetapi mempunyai konsekuensi yang luas bagi budaya dan nilai-nilainya. Hingga disadari ada beberapa kelompok mesyarakat yang mengambil modernitas dengan cara pragmatis yang berakibat terputusnya tanpa terduga hubungan dengan tradisi intelektual historis tertentu yang telah ada.

Padahal perlu dilakukan pencirian khusus secara ideologis yang bisa diajukan untuk menyatukan masa kini dengan masa lalu dalam cara yang berbeda-beda, demi terpeliharanya kontuinitas. Disamping itu proses kebangkitan dengan mengupayakan terjadinya pembaharuan (tajdid) dan ijtihad (pemikiran bebas) berperan sebagi kunci di bawah rubrik memikirkan kembali pengkajian Islam. ${ }^{10}$ Perhatian utama dari itu semua adalah mempersiapkan dasar-dasar bagi pemikiran ulang dunia pendidikan agar secara bertahap dapat direalisasikan melalui kurikulum pembelajarannya. Salah satu wilayah pembaharuan pendidikan yang paling banyak diabaikan dalam pandangan tersebut adalah sistem pendidikan ulama yang tradisionalkonservatif. Sektor inilah yang dianggap paling banyak menentang perubahan yang

${ }_{10}$ Muhammad Iqbal. 1986. The Reconstruction of Religious Thought in Islam. Lahore, Ashraf. h. 5-8 diakibatkan oleh budaya dan intelektual modernitas (globalisme). Ia hanya terhenti pada "ana al-haq" yang bersifat formal keagamaan. Akibatnya, pandangan sepihak tersebut dapat mengorbankan masyarakat secara umum, karena hal inilah dunia Muslim tertinggal di belakang masyarakat kontemporer lain yang telah mengembangkan sesuatu yang dianggap "gaib" sebelumnya dan mampu menemukan berbagai ana al-haq lainnya hingga elaborasi nilai dan kontekstualitas kehidupannya dapat diatasi dalam kesemestaan aspek, seperti budaya, ekonomi, politik, sosiologi dan ilmu lainnya. Sesungguhnya perbedaan itu dapat sedikit diatasi dengan melandaskan diri pada nilai-nilai aksiologis dan epistemologis ilmu pengetahuan. Harapannya, perpaduan tersebut dapat membuka ruang perjumpaan ana al-haq antara satu dengan lainnya.

\section{Sikap Seimbang Menghadapi Kompleksitas Globalisasi Agama dan Budaya Masyarakat}

Sikap perguruan tinggi agama dalam menghadapi gegap gempitanya globalisasi, jika masih berpegang pada wawasan tradisi keilmuan ulama-konservatif yang formalis keagamaan, pastilah akan menghadapi berbagai kesulitan. Kesulitan itu misalnya terjadi stagnasi antara ilmu, agama dan teknologi, disamping secara praktis akan berdampak pada keterputusan para lulusan dengan dunia ketenagakerjaan sebagai demand phenomenanya. ${ }^{11} \quad$ Kemungkinan

\footnotetext{
${ }^{11}$ Demand phenomena merupakan istilah pembangunan developmentalisme yang berarti permintaan dan ketergantungan. Permintaan diartikan sebagai suatu kondisi dan situasi yang memberikan suatu kebijakan untuk memperhatikannya, karena kondisi tersebut merupakan sesuatu faktor penarik ketika suatu program akan dilakukan. Istilah ini kemudian lebih banyak digunakan pada sektor pendidikan karena adanya ketersinggungan dengan teori human capital dan kredensialisme yang berhubungan antara sistem pendidikan dengan dunia ketenagakerjaan. Pada tulisan ini diartikan sebagai kondisi penarik yang harus dipenuhi kebutuhannya. Kemiskinan dijadikan sebagai demand phenomena karena ia suatu ketergantungan yang mempersyaratkan suatu perhatian dari kebijakan. Selanjutnya dapat dilihat dalam A.R. Tilaar. 1994.
} 
besar, hal ini akan bertahan atau lebih buruk jika pengkajian ilmu yang ana alhaq masih didasarkan pada self interest seperti yang terjadi selama ini. Sementara itu, pengembangan ilmu dan teknologi akan selalu dihadapkan pada tantangan bagaimana mengatasi masalah global dan kontekstual. Lalu jika perguruan agama seperti UIN/IAIN/STAIN masih menggunakan paradigma lama, mungkinkah ia memberikan kontribusi positif bagi isu-isu global dan kontemporer yang dihadapi penganut agama dan masyarakat luas?

Jika masalah kontekstualitas budaya diperhatikanlebihlanjut,makaterjadisemacam homogenisasi kebudayaan dalam konteks globalisasi yang juga harus dikualifikasikan dengan berbagai perkembangan sebaliknya. Tiga kecenderungan yang dapat disebutkan pada suatu realitas budaya adalah adanya: (i) kecenderungan menghindar dari perubahan, karena perubahan tidak diinginkan (bisa pada satu kemungkinan dianggap membahayakan dominasi terhadap fasilitas yang dimilikinya, terlihat sekali di berbagai STAIN lokal); (ii) kecendrungan untuk kembali ke tradisi ditengah proses marginalisasi yang menyeretnya pada persoalan memecahkan permasalahan kontemporer dengan mata pisau masa lampau, yang pada akhirnya ia telah kehilangan keautentikan dirinya yang bersifat institusional ataupun otonomi kesadarannya. ${ }^{12}$ Pola pikir seperti ini, disebut oleh sivitas IAIN Sunan Kalijaga Yogyakarta dahulu, sebagai "terlalu 'nyar'iah" karena masih terbelenggu pada penafsiran naratif literer dari tradisi Islam. Pandangan ini kerap dianggap sebagian orang tidak memungkinkan berkembangnya daya kreasi pemikiran. Tradisi ini oleh angkatan muda selanjutnya sedikit

Manajemen Pendidikan Nasional: Kajian Pendidikan Masa Depan. Bandung: Remaja Rosada Karya), h. 96-102

12 Robert D. Lee. 2000. overcoming Tradition and Modernity: the Search for Islamic Authenticity diterjemahkan Mencari Islam Autentik. Bandung: Mizan. h. 11 demi sedikit direkonstruksi dengan pola pikir kontekstual, atau biasa disebut dengan gerakan paradigma hermeneutik.

(iii) kecendrungan menggunakan budaya atau identitas budaya untuk tujuan-tujuan ekonomi politik. Kecendrungan ini secara umum terlihat dengan memanfaatkan identitas budaya yang dibungkus dengan ideologi pembebasan dan propaganda sebagai komoditas politik. Kecendrungan semacam ini dalam pengembangan ilmu pengetahuanagama di IAIN terlihat pada pembedaan kalangan kaum sarungan (Nahdlatul Ulama) dan kaum celana (Muhammadiyah) dalam penguasaan atau dominasi yang tentunya memberi pengaruh terhadap penyusunan sistem pendidikan yang dikembangkan di perguruan tinggi agama Islam. Pendekatan kultural yang digunakan oleh kalangan NU dalam pengkajian ilmu menuntut pada pemahaman budaya lokal sebagai starter point, yang hal ini secara langsung ditentang oleh kalangan Muhamadiyah dengan jargon TBC-nya. Akhirnya dinamika pengembangan keilmuan akan tergantung besar kepada siapa yang menguasai dan mendominasi fasilitas sebagai latencynya dan goalnya. ${ }^{13} \mathrm{Hal}$ ini tidak dapat dipungkiri dalam pengkajian Islam di UIN, IAIN, dan STAIN.

\section{Digunakannya Kerangka Epistemologis yang Holistik dan Berwawasan Ekologis}

Nilai ini berintikan pada semangat universalitas dan intertekstualitas terhadap ruang dan waktuhingga mempunyai kepedulian terhadap peradaban dan kebudayaan yang sedang dan telah dialami manusia (culture materialisme). Pengembangan wawasan terhadap epistemologi sangat erat kaitannya dengan pengembangan wawasan keilmuan. Sekalipun epistemologi adalah cabang filsafat, tetapi pemahaman terhadap epistemologi besar manfaatnya dalam pengembangan ilmu, sebab pemahaman terhadap hakikat dari

\footnotetext{
${ }^{13}$ Parson., op. cit., h. 36
} 
suatu ilmu dipelajari dari segi filsafat khusus. Kesulitan-kesulitan dalam pengembangan ilmu pengetahuan di perguruan tinggi agama adalah menemukan hakikat dari kesejatian dirinya, karena masih dibenturkan pada pengelompokan ilmu itu sendiri baik disadari atau tidak disadarinya. Keterlepasan dari epistemologi ilmu humaniora dan sosial yang cenderung holistik dan ekologis ataukah tetap berada pada kawasan ilmu-ilmu agama yang bersifat formal dan partikular, merupakan perjuanganyang tidak ringan dan harus dijawab dengan segera sebagai acuan pengembangan.

Islam bila dilihat dari segi pengembangan ilmu menimbulkan berbagai sudut pandang, baik dari segi internal maupun eksternal. Pengembangan ilmu dari segi internal (Tafsir, Hadits, Fiqh, Ushul Fiqh, Balaghah, Kalam, dan sebagainya) sudah berjalan cukup memadai, sekalipun masih perlu terus ditingkatkan sejalan dengan perkembangan yang terjadi di dalam masyarakat. Sedangkan perkembangan ilmu dari segi ekternal (filsafat, sosiologi, antropologi, filologi, dan sebagainya) justru sebaliknya, masih belum memadai, kalau boleh dikatakan justru mengalami kemunduran bila dibandingkan dengan abad-abad permulaan Islam. Pengembangan ilmu yang bersifat eksternal di perguruan tinggi agama belumlah mendapat perhatian yang serius (dapat dilihat dari hasil penelitian Disertasi IAIN Sunan Kalijaga pada periode 2000-2007 kebanyakan masih berada pada dataran ilmu internal [ilmu pokok]), pelaku ilmu masih banyak menyibukkan diri dengan pemikiran terkotak yang menimbulkan pergeseran intern yang berakibat melelahkan dan melengahkan, sehingga memperkecil daya gerak pikir yang memiliki konsep pengembangan ilmu yang bersifat eksternal. Belum lagi dihubungkan secara ekologis dalam intertekstualitas keilmuannya.

Penemuan metode, penajaman dalam wawasan terhadap sistem keilmuan, penghayatan terhadap perlunya pengembangan epistemologi yang holistik (internal dan ekternal serta dengan sudut pandang ekologis) diharapkan dapat melahirkan dinamisasi yang kreatif, munculnya usaha yang tangguh, bukan saja menemukan perumusan-perumusan yang kontekstual tetapi juga prediktif atau hingga mencapai taraf verstehen yang heuristik (problem solving). ${ }^{14}$ Munculnya pandangan "Islam menjawab tantangan zaman" yang selalu menjadi jargon UIN/IAIN/STAIN dirasa tidak cukup bahkan tidaklah pantas dikemukakan. Artinya hal itu hanya akan menimbulkan budaya yang tidak kreatif dan terjebak pada keikatan tradisi literer naratif yang kaku dan mengembalikan segala sesuatu kepada al-Qur'an dan hadis, hingga seolaholah ia hanyalah merupakan gudang amunisi dalam penyediaan sarana perang atau gudang makanan bagi orang yang kelaparan. Karena pelaku ilmu hanya menunggu masalah yang muncul, baru ditantang dan dijawab. Budaya menunggu inilah budaya yang tidak kreatif dan melemahnya pandangan yang bersifat prediktif, dan tercermin tidak mempunyai landasan holistik dalam suatu konteks ekologis yang ada.

Mungkin keterukuran holistik dan ekologis ini tidak dapat tercover oleh kajian ilmu di perguruan tinggi agama karena masih melihat pada suatu segi fungsinya belum pada taraf operasionalisasi dari desain fungsi itu sendiri, yaitu pertama, ilmu yang berpandangan statis, yaitu bahwa ilmu itu merupakan kegiatan yang sistematis dalam rangkaian hanya mengumpulkan dan memberikan informasi tentang berbagai masalah. Di sini memang tampak tugas pada ilmuwannya hanya menemukan fakta baru. Ilmu dalam pandangan ini juga diartikan sebagai jalan untuk memberikan penjelasan tentang masalah yang sedang dipersoalkan. Kedua, ilmu yang berpandangan dinamis, yaitu ilmu itu lebih dari hanya sekedar kegiatan saja, tetapi merupakan tuntutan dari pelaku ilmu apa yang harus dikerjakan dengan ilmu itu. Kegiatan

${ }^{14}$ Fred N. Karlinger. 1974. Foundation of Behavioral Research. New York: Holt Renehart and Winsten, Inc. h. 8 
dan tuntutan itu diwujudkan dalam penelitian dan dasar-dasar teori ilmiah. Pandangan ini disebut sebagai pandangan heuristik, yang artinya menemukan dan mengungkapkan atau lebih tegas dikatakan problems solving. Ilmu yang heuristik berarti lebih menekankan segi pemecahan masalah dari pada sekedar menemukan fakta saja dan memberikan informasi. Dari ilmu yang berpandangan dinamis ini dapat diperoleh dua fungsi ilmu, yaitu: fungsi praktis, pengembangan ilmu dalam rangkaian usaha peningkatan taraf hidup lahir batin, kehidupan manusia yang lebih baik dan utuh; dan fungsi perumusan hukum dan penciptaan prediktif.

\section{Pembedaan Antara Unsur-Unsur Lokal Dan Universal, Serta Interplay Keduanya}

Nilai ini bertumpu pada suatu sikap lokalitas dan aspek universalitas dalam suatu ruang perjumpaan ilmu dengan kontekstualitas masyarakatnya. Persoalan yang kemudian dikaitkan dengan pengetahuan adalah untuk menjelaskan bagaimana sebenarnya origin of knowledge yang cocok untuk di perguruan tinggi agama. Artinya dengan daya apakah pengetahuan itu dapat diperoleh. Dalam percampuran epistemologi ilmu modern tentunya tertumpu pada dua aliran besar, yaitu rasionalisme dan empirisme. Akal sebagai sumber ilmu pengetahuan dengan melahirkan konsep-konsep, sedangkan epistemologi atas dasar pengalaman juga melalui "innersense" seperti refleksi dan introspeksi.

Dalam filsafat ilmu Barat misalnya, Kant memang berhasil untuk memadukan antara unsur rasionalisme dan empirisme. Apakah sumber ilmu itu hanya terbatas pada rasionalisme dan empirisme? Manusia seolah-olah membatasi diri pada sumber ilmu yang bersifat rasional/dan atau empirik saja. Pada mula perkembangan dari rasionalisme dengan metode skeptiknya menyatakan bahwa Tuhanlah yang menjamin kebenaran akal dengan ide innatenya, bahwa ide innate adalah pemberian Tuhan sejak manusia lahir. Empirisme dengan keyakinan bahwa pengetahuan itu hanya diperoleh secara empirik atau berdasar pengalaman, mudah cenderung untuk menolak kebenaran tentang Tuhan, karena Tuhan pastilah bukan sesuatu yang dapat diempirik, mudah cenderung untuk bersikap ateis. Empirisme harus dibedakan secara tegas dengan empirik. Empirik suatu sikap yang menyatakan terhadap sesuatu yang dapat diempirik, siapapun juga dapat menerima kenyataan terhadap adanya sesuatu yang dapat diempirik, tetapi empirisme adalah aliran yang menyatakan asal usul/sumber pengetahuan hanya dari sesuatu yang empirik saja dan yang terakhir inilah yang mudah cenderung menjadi bersikap ateis. Sekalipun empirisme mudah menjadi ateisme, John Locke masih tetap mempertahankan keyakinan adanya Tuhan dengan menyatakan bahwa Tuhan ada dapat dilihat dari segi: demonstative knowledge, ketertiban alam semesta secara demonstratif memberikan pengetahuan bahwa Tuhan itu ada.

Jika asal usul pengetahuan hanya dua aliran yang memegang peran, maka amatlah sulit dan berat tugas pengembangan keilmuan di perguruan tinggi agama, karena ilmu agama Islam ditempatkan diluar lingkup epistemologi dan tidak berhak menyusun kelompok ilmuilmu sendiri, atau cukup dimasukkan dalam ilmu-ilmu humaniora dan atau ilmu-ilmu sosial budaya. Sebab itulah yang terpenting adalah mampu mengcover dan mengakomodasi "keberagamaan" serta memberikan rasa antara rasio dengan tindakan sebagai nilai spiritualitas dari keilmuan lainnya

Oleh karenanya persoalan metodologi dalam pengembangan keilmuan di perguruan tinggi agama menghadapi persoalan yang cukup sulit. Pada satu sisi terdapat sikap agnostic dan skeptik terhadap pengembangan ilmu-ilmu agama, sedangkan pada sisi lain agama dan pelaku ilmunya harus mampu menjawab harmoni lokal dan universalitas kondisi masyarakat. Padahal yang 
menjembatani itu adalah penguatan terhadap metodologi penelitian agama, meskipun tidak meninggalkan metodologi penelitian sosialnya. Jika pada ilmuwan lebih cenderung menggunakan metodologi penelitian sosial untuk berbagai bidang ilmu di UIN/IAIN/ STAIN dapatlah dianggap wajar. Penggunaan metodologi ini dilakukan secara sadar ataukah sebagai manifestasi sikap agnostic dan atau skeptik terhadap metodologi penelitian agama perlu dipertanyakan. Pengembangan metodologi adalah bagian yang tidak kalah pentingnya dalam rangka pengembangan suatu ilmu. Memang diakui bahwa dalam rangka pengembangan, apakah itu ilmuilmu pasti/alam, ataukah ilmu sosial dan humaniora secara epistemologis bergerak dalam dua solusi: secara deduktif atau induktif dan hipotesis. Kasus deduktif seperti metode dialektika (Hegel) dan metode transendental (Kant). ${ }^{15}$

Meskipun pengembangan epistemologi di satu sisi juga menghadapi masalah struktur pengembangan ilmu. Pola pengembangan ilmu ini dibangun atas dasar obyektif atau subyektif. Dua relasi bangunan subyek atau obyek yang menjadi domain of relation. Obyek tidak akan hidup dan berkembang menjadi ilmu tanpa subyek, dan subyek tidak akan dapat mengembangkan ilmu tanpa obyek. Akan tetapi persoalannya menjadi lain apabila pola pengembangan itu subyektivisme dan obyektivisme. Memang sikap subyektivisme banyak kelemahan, tetapi obyektif seratus persen adalah tidak mungkin. Terkadang orang mencoba untuk bersikap pan-obyektivisme yaitu keobyektifan yang ditelusuri dari berbagai obyek yang terkait, juga kelemahan subyektivisme ditutup dengan pandangan intersubyektif, artinya pengakuan ahli ilmu yang sejenis atau ahli ilmu lain akan valid dan realablenya ilmu yang dikembangkan cukup memberi bukti obyektif ilmu tersebut.

${ }^{15}$ Dagobert D. Runes. 1963. Dictionary of Philoshophy. New Jersey: Littlefield, Adams\&Co. h. 95

\section{Dilibatkannya Nilai Spiritual yang Berasal Dari Sumber-Sumber Transenden.}

Standar ini telah terdapat pada segisegi pengembangan ilmu dan pendidikan di perguruan tinggi agama dan bukan hanya dari segi internal saja tetapi mungkin juga dari segi eksternal. Islam yang menjadi watak dalam pengembangan ilmu baik internal ataupun eksternal diakui secara intersubyektif sebagai "islam, the last of the nostalgia religions, radically monotheisme and, in ortodox form, soberly adjusted to this world. ${ }^{16}$ Pandangan Islam jelas dan tegas; Islam berpandangan monotheistik dan bersikap ortodoxs, serta mempunyai kemampuan untuk menyesuaikan diri secara bijaksana terhadap dunia sekitarnya yang dihadapi dengan tidak usah menghilangkan jiwa dan semangat kepribadiannya (otentik tetapi tidak meninggalkan budaya lokal dan semangat universalitasnya) atau identik dengan gerakan multikulturalisme.

Islam mendorong manusia untuk meneliti alam semesta guna kepentingan hidup manusia di dunia ini, meneliti rahasia alam semesta sehingga dapat diketahui kebesaran Tuhan. Dengan mengadakan penelitian tersebut akan mendapatkan demonstative knowledge "makna agama dalam ayat kauniyah" yang pada gilirannya akan menghasilkan internalisasi keberagamaan. Sesungguhnya kedudukan akal di dalam al-Qur'an sangat potensial. Ia mendapat tempat yang terhormat di dalam sistem pengembangan ilmu-ilmu agama Islam. Tentunya ia mampu melibatkan unsur-unsur spiritual dari suatu sistem pengembangan ilmu. Namun bagaimana kemudian menemukan dan mengembangkan sistem berpikir yang tepat itu.

Ada dua hal yang perlu dicermati dalam menjalin unsur-unsur spiritual ini, pertama pemahaman terhadap sistem itu sendiri

${ }^{16}$ Gustave R Van Grunebaum. 1976. Islam and Medieval Hellenism, Social and Cultural Perspective. London: Variroum Reprints. h. 21 
dan kedua adanya usaha pengembangan aspek pengkajian dan penelitian. Hal yang pertama meliputi upaya dan kegiatan ilmiah dalam menemukan sistem dan metodenya. Amin Abdullah, misalnya, telah menawarkan sistem horizon payung, Ismail Raji al-Faruqi menawarkan Islamisasi ilmu pengetahuan ${ }^{17}$ yang kemudian didukung oleh Ziauddin Sardar ${ }^{18}$ dan Osman Bakar, sedangan Teuku Yakob menawarkan adanya hubungan simetris antara ilmu pengetahuan, teknologi dan agama pada bingkai kemajuan. ${ }^{19}$ Keseluruhan susunan itu sendiri dinilai telah kritis, dan dipertimbangkan apakah sebagai keseluruhan yang sudah selengkapnya mencakup segala sesuatu yang seharusnya bernaung di dalamnya. Kemudian kalau sistem itu sendiri diartikan sebagai susunan relasi-relasi yang ada pada suatu realita. Ini berarti di dalam membicarakan sistem terkait dengan obyek. Kekhususan dalam ilmu menyangkut obyek formal di dalam suatu sistem ilmu itu, disamping juga adanya obyek material yang bisa dijadikan sasaran yang dapat dijadikan obyek pengkajian. Sasaran yang dimaksud dapat berupa barang, hal, kejadian, gejala, dan lain-lain yang pantas untuk dapat dikaji. Sedangkan obyek formalnya akan mengangkat aspek khusus pengkajian itu dilakukan hingga belum tentu hasilnya sama ketika dilakukan pengkajian. Pengkajian ilmu haruslah bersifat: sistematis ilmiah dan obyektif. Maka semakin tajam pengkajian yang menekankan pada obyek formal akan makin masuk dalam rangkaian closed system.

Dalam pengembangan ilmu agar mandiri maka para pelaku ilmu haruslah tetap konsisten dalam berpikir dalam rangkaian satu sistem (thinking system) dan menganalisa dalam rangkaian satu sistem (analysis system). Disinilah kemudian masing-masing kelompok

\footnotetext{
${ }^{17}$ Ismail Raji al-Faruqi. 1985. Islamisasi Pengetahuan. Bandung: Mizan. h. 24

${ }^{18}$ Ziauddin Sardar. 1987. Masa Depan Islam. Bandung: Pustaka Salman. h. 88

${ }^{19}$ Teuku Yacob. 1984. Islam, Pengetahuan dan Teknologi. Bandung: Mizan. h. 26-30
}

ilmu itu tidak dapat mempertahankan sistem tertutup, karena masing-masing ilmu tidak dapat menyelesaikan masalah kontekstual manusia yang semakin kompleks dengan berdiri sendiri menanganinya, masing-masing butuh saling tukar informasi dengan menganut sistem terbuka. Itulah rangkaian pendidikan integral yang holistik, ekologis, dan universal dalam bingkai "keberagamaan."

Oleh karenanya ilmu-ilmu agama (jika kita setuju adanya pengelompokan ilmu) butuh ilmu-ilmu sosial budaya, sedangkan bagi ilmu humaniora, teknologi, sosial dan sebagainya tetaplah harus dijiwai oleh nilainilai spiritual yang transendental. Ilmu untuk demi kepentingan ilmu sudah mulai dianggap usang, mulailah membangun sudut pandang ilmu yang digunakan untuk kesejahteraan umat manusia secara lahir dan batin, mulai dibangun pendekatan multidisipliner dan interdisipliner dalam mengembangkan ilmu di perguruan tinggi agama seperti yang terlihat, meskipun sekali lagi perlu ditegaskan hubungan keduanya, apakah bersipat (jika meminjam istilah budaya) assimilasi, akulturasi dan sintetis ataukah bersifat menumpuk dan membayanginya saja.

Sedangkan pengembangan aspek pengkajian dan penelitian akan melihat secara jauh dalam pembinaan ilmu-ilmu agama Islam sebagai bagian ilmu agama. Tinjauan dari segi aspeknya berarti penataan obyek formalnya. Pemahaman dari segi obyek formal adalah hak dari setiap ahli apapun keahliannya. Perluasan wawasan obyek formal sekaligus munculnya pengakuan terhadap keilmuan baru disebabkan karena dikembangkan segi-segi yang mengangkat obyek formal itu. Dengan demikian obyek formal dalam pengembangan ilmu-ilmu agama itu bukan satu aspek saja, bisa juga lebih dari satu aspek. Adanya dinamika keilmuan itu karena pengembangan wawasan obyek formalnya. Dinamika dan obyek formal adalah dua sisi dari mata uang, dua rangkaian dalam pengembangan ilmu atau bahkan penemuan ilmu baru. Contoh yang dapat 
diajukan adalah munculnya masalah Bank Muamalah Syariah, itu dikarenakan adanya dinamika kebutuhan pelayanan terhadap umat, atau menjawab tantangan masalah bank timbullah kajian tentang bank. Pengkajian seperti ini dilihat dari aspek Islam, tetapi tentang masalah ekonomi dalam Islam sendiri belum muncul pengkajian secara intens, maka ia mengambil obyek material dan obyek formal dari ilmu ekonomi umum.

Dinamika yang terjadi dalam masyarakat, dampaknya akan meresap ke dalam pengembangan keilmuan dan proses pembelajaran di UIN/IAIN/STAIN, sebab ketiganya juga sebagai lembaga Pendidikan Tinggi yang bertujuan mengembangkan dan menyebarluaskan ilmu pengetahuan dan mengupayakan penggunaannya untuk meningkatkan taraf hidup masyarakat. Demikian halnya misalnya tentang masalah psikologi, antropologi, arkeologi, dan ekonomi sendiri mungkin di UIN/IAIN/STAIN masih merupakan mata kuliah yang bersifat pilihan, meskipun civitasnya telah mengetahui dasardasar yang dapat dikembangkan. Yang paling perlu dibenahi adalah masalah pengembangan aspek pengkajiannya, terutama ditujukan dalam pengembangan ilmu-ilmu yang bersifat eksternal. Disamping memberikan hubungan simetris dan perannya dalam kajian keagamaan, sehingga akan menjurus pada pendidikan yang bersifat integral.

Perlu dicatat bahwa kekuatan sipiritual yang diajarkan al-Qur'an dan Hadis telah membimbing manusia untuk gemar membaca dan menulis, dan juga menyiratkan tiga aspek pokok ilmu pengetahuan: pertama, aspek etik termasuk aspek-aspek perceptual dalam ilmu pengetahuan; ini berkaitan dengan prinsip dasar mengenai keyakinan, perbuatan dan moralitas, baik untuk perorangan maupun kemasyarakatan, dan dengan pandangan yang merupakan sistem atau pandangan hidup yang sempurna, demi tercapainya kehidupan yang terbaik di dunia ini dan tercapainya "posisi kemanusiaan yang tertinggi”; kedua, aspek historis dan psikologis, berkaitan dengan berbagai sikap dan cara berpikir manusia dan bangsa yang terikat atau menyimpang dari norma-norma yang diberikan oleh agama -berbagai sikap dan cara berpikir mereka terhadap kebenaran dan realitas dan yang bertanggungjawab terhadap berbagai konsekuensi yang timbul; dan ketiga aspek observatif dan eksperimental telah berkalikali ditekankan sebagai sumber utama untuk memperoleh ilmu pengetahuan tentang benda-benda, tentang hubungan antar benda, fenomena alam dan sosial kemasyarakatan dan sebagainya. Sekarang hal ini sama benar dengan ancangan ilmiah modern yang mencoba menghindari persoalan-persoalan metafisik dan yang tidak tertarik dengan segala sesuatu di luar realitas yang bersifat fisik.

Penting sekali bahwa ketiga cara untuk memperoleh ilmu pengetahuan itu merupakan satu-satunya alat untuk menempatkan prinsip tauhid sebagai "faktor yang berperan dalam kehidupan intelektual dan emosional manusia yang merupakan landasan spiritual Islam yang tertinggi". Meskipun konsep ilmu pengetahuan yang purna-dimensional ini diawali dengan pengetahuan tentang benda-benda yang dapat dipersepsi, kemudian mentransendensikan bidang ini. Tentunyapun penyadaran akan konteks manusia dalam makna historis harus diajukan untuk melihat perubahan situasi dan kondisi fisik, politik, hak kultural manusia, sosial, dan ekonomik mendorong setiap generasi untuk lebih menaruh perhatian terhadap ilmu-ilmu dalam kesejarahannya masing-masing ${ }^{20}$ hingga bahan-bahan ilmu yang dijahit oleh sivitas perguruan tinggi agama akan bermanpaat bagi manusia dengan melindunginya dari kebekuan peradaban, panasnya gejolak moralitas, dan duri-duri negatif globalisasi.

${ }^{20}$ Abdullah Ahmad an-Naim. 1990. Toward an Islamic Reformation: Civil Liberties, Human Rights, and International Law. New York: Syracuse University Press. h. 5 


\section{Perumusan Praktik Pendidikan Integral}

Perguruan tinggi sebagai pencipta dan perajut pendidikan integral haruslah dirawat dengan baik, sendi-sendi kompetensi keilmuan para sivitasnya perlu didorong dan difasilitasi, ruang-ruang bereksistensi perlu diperluas, kepekaan para sivitas terhadap dunia eksternal harus tetap dilatih, kurikulum pendidikannya harus dibuat secara holistik dan integral. Kesempurnaan dan kewibawaan perguruan tinggi agama yang menerapkan sistem pendidikan integral akan menghasilkan para lulusan yang bagus, halus, sempurna, dan peka terhadap dunia di luar identitas dirinya. Kapasitas perguruan tinggi agama tersebut ditentukan oleh sistem struktur dari tempat pengkajian dan pendidikan berbagai ilmu itu dilakukan, dan didukung oleh mahasiswa dan pelaku ilmu lainnya, serta penetapan dan konsistensi paradigma yang menentukan berjalannya pengkajian dan pendidikan integral yang ada. Bisa jadi, ia bisa mengambil model trend tradisional plus, ia juga mampu mengambil trend punk, trend budaya pop, dan sebagainya. Yang menjadi pokok persoalan adalah bagaimana merumuskan struktur dan paradigma itu sendiri? Karena sivitas atau para pelaku sebenarnya masih bersifat tabulasa, sesuai dari apa yang akan diukir oleh sistem dan paradigma tersebut.

Azyumardi Azra pernah mengajukan beberapa rekomendasi untuk pengembangan perguruan tinggai agama seperti UIN/IAIN/ STAIN, sebagai berikut: Pertama, reformulasi tujuan IAIN. Keinginan ke arah center of learning and research atau center of Islamic thought harus lebih diutamakan daripada sekedar training center hingga mampu menjadi penggerak pembaharuan pemikiran Islam; kedua, restrukturisasi kurikulum, dengan menawarkan ilmu-ilmu umum berjalan bersama dengan Islamic studies, sehingga akan menghasilkan pendidikan yang integral. Hal ini bersesuaian dengan pelaksanaan standar ketiga dan prinsip akomodasi ana al-haq sebagaimana disebutkan di atas; ketiga, simplikasi beban perkuliahan, dengan membuang mata kuliah yang tidak berkait erat dengan tujuan model paradigmanya; keempat dekompartementalisasi hingga mencapai keilmuan yang utuh tidak terpotong-potong; dan kelima liberalisasi sistem SKS untuk memberikan ruang kebebasan sesuai dengan inner power dari para pelaku ilmu. ${ }^{21}$

Perumusan yang ditawarkan Azra di atas sangat baik, tetapi perlu ditambahkan tentang usaha penumbuhan kesadaran para pelaku ilmu di perguruan tinggi agama akan responnya terhadap budaya lokal, kontekstualitasnya dengan kondisi masyarakat, dan akses masuk dalam jaringan-jaringan non keagamaan yang dapat memberinya inspirasi untuk mewarnai dan diwarnai dari dan terhadap kajian keilmuannya. Dengan demikian akan memperkaya horizon keilmuannya. Di samping itu, para pelaku ilmu di perguruan tinggi agama seringkali terjebak pada masalah urgennya bahasa asing sebagai tolak ukur dari kemampuan dan kecerdasan pengkajian. Disadari bahwa kemampuan bahasa asing hanyalah salah satu alat dari berbagai alat pengkajian. Kemampuan bahasa lokal rupanya tidak direspon positif. Pada akhirnya ada kecenderungan bermain di atas pendapat tokoh asing atau bahkan ada kecendrungan menjadi peniru yang menenggelamkan kreativitas kemampuan dirinya. Karena orang yang ahli bahasa asing (dan kebanyakan) belum tentu mempunyai keahlian imajinatif, kemampuan intuitif, kemampuan fantasi, kemampuan merasakan gejala (fenomena) sosial, sain, dan teknologi.

Pada sisi lain kemampuan mengakomodasi ana al-haq keagamaan pada ruang culture materialisme yang sesungguhnya mampu menciptakan standarisasi holistik, integral, dan ekologis tidak diupayakan dalam kerangka sistem pendidikan. Akibatnya seliberalnya pelaku ilmu di perguruan tinggi agama dalam

${ }^{21}$ Azyumardi Azra. 1999. Pendidikan Islam: Tradisi dan Modernisasi Menuju Milenium Baru. Jakarta: Logos. h. 165168 
melihat konsep keagamaan akan kembali jatuh pada suatu normativitas dan formalitas keagamaan. Hal ini akan menjadi suatu kelucuan intelektual yang bias atau berada di atas antara langit dan bumi. Sesungguhnya hal yang sangat menarik jika culture materialisme digunakan dalam mengkaji naskah literer naratif keagamaan, misalnya Fiqh telah menghukum haram babi. Mengapa babi bisa diharamkan, apakah karena semata-mata naskah keagamaan atau ada tujuan ekologis dibalik itu semuanya? Perhatikan misalnya bagaimana kebudayaan dan lingkungan hortikultura saling berkaitan di antara orangorang Arab yang hidup di pedalaman Timur Tengah, dan masih banyak hal yang perlu dikontekskan dengan segera. Itulah tugas perguruan tinggi agama dalam menemukan dan mengakomodasi serta mengcover ana alhaq ilmu dalam ruang dan waktu hingga kita menemukan "keberagamaan kontekstual"

\section{PENUTUP}

\section{Simpulan}

Pendidikan integral antara keilmuan sosial kebudayaan dengan ilmu keagamaan di perguruan tinggi sepenuhnya ditentukan oleh sistem struktur dan paradigma keilmuan yang diletakkan kepada para sivitasnya. Apabila struktur dan paradigma keilmuan yang dikembangkan hanya sebatas pengenalan dan proses internalisasi keagamaan secara internal, maka para sivitas akan terjebak pada pemikiran yang sempit dan terbatas. Sementara bila kajian keagamaan tersebut kemudian diintegrasikan dengan keilmuan lain, khususnya ilmu yang masuk dalam kajian sosial kebudayaan, di mana konteks kultural dan aspek-aspek sosiologi masyarakat dapat menjadi sudut pandang dari peristiwa dan praktik keagamaan, maka perguruan tinggi tersebut akan melahirkan para sivitas yang mampu memetakan, menjelaskan dan memikirkan ilmu agama secara kontekstual. Selain itu, kepekaan untuk membaca dan menjawab isu-isu kontemporer pun akan semakin terasah dan berwujud nyata dalam perannya di masyarakat. Akhirnya, perguruan tinggi agama seperti UIN/IAIN/ STAIN tentu bisa menjadi center of learning and research, sekaligus menjadi agen perubahan di masyarakat.

\section{Rekomendasi}

Tulisan ini mengusulkan kepada Kementerian Agama, terutama Direktur Jendral Perguruan Tinggi Islam untuk memberikan dan mendorong perguruan tinggi agama bisa menumbuhkan kesadaran dan kecenderungan kajian para sivitasnya kepada budaya lokal, budaya populer, konteks kekinian dan geo-historis masyarakat, dan ruang-ruang eksternal kajian non keagamaan. Salah satu caranya adalah menyusun kembali kurikulum metodologi penelitian yang tidak hanya pembacaan terhadap masalah-masalah keagamaan, tetapi perlu diperluas dengan membaca dan memahami aspek-aspek geohistorisnya. Sementara laboratorium sosial teknologi pun bisa didirikan di perguruan tinggi agama sebagai implementasi struktur dan paradigma keilmuan yang integral antara ilmu-ilmu keagamaan dengan ilmu sosial kebudayaan, dan teknologi.

\section{SUMBER BACAAN}

Abdullah,M. Amin, "Pengembangan Kajian Ke-Islaman: Metode dan Pendekatannya Pada Program Pascasarjana UIN/IAIN/ STAIN" makalah yang disampaikan pada semiloka Pengembangan Program Pascasarjana IAIN di Padang tanggal 26-28 Desember 2002, dan diulanginya pada kesempatan Seminar Internasional Pemikiran Abdullah Ahmad an-Naem, di Radisson Hotel Yogyakarta pada tanggal 8 Januari 2003. pemikiran ini pula termuat pada tulisannya "Kajian Ilmu Kalam di IAIN: Menyongsong Perguliran Paradigma 
Keilmuan Keislaman pada Era Milenium Ketiga" dalam al-Jamiah, No. 65/VI/2000.

Azra, Azyumardi. (1999): Pendidikan Islam: Tradisi dan Modernisasi Menuju Milenium Baru. Jakarta, Logos

Faruqi, Ismail Raji al-. (1985): Islamisasi Pengetahuan. Bandung, Mizan.

Grunebaum, Gustave R Van. (1976): Islam and Medieval Hellenism, Social and Cultural Perspective. London, Variroum Reprints.

Giddens, Anthony. (1976): New Rules of Sociological Method. New York, Basic Books.

Habermas, Juergen. (1979): Communication and the Evolution of Society. Boston: Beacon Press

(1971): Knowledge and Human Interest. Boston, Beacon Press.

Iqbal, Muhammad. (1986): The Reconstruction of Religious Thought in Islam. Lahore, Ashraf.

--------. (1987): Javid Namah: Kitab Keabadian.Jakarta, Pustaka Panjimas.

Karlinger, Fred N. (1974): Foundation of Behavioral Research. New York, Holt Renehart and Winsten, Inc.

Koentowijoyo. (1997): Muslim Tanpa Masjid. Yogyakarta, LkiS.
Lee, Robert D. (2000): Overcoming Tradition and Modernity: the Search for Islamic Authenticity diterjemahkan Mencari Islam Autentik. Bandung, Mizan.

Naim, Abdullah Ahmad an-. (1990): Toward an Islamic Reformation: Civil Liberties, Human Rights, and International Law. New York, Syracuse University Press.

Parson, Talcott. (1951): The Social System. Glencoe: The Free Press.

Ricouer, Paul. (1991): From Text to Action: Essay in Hermeneutics II, .Evanston Illinois: Northwestern University Press.

Rappaport, Andrew P. Vayda dan Roy A. (1968): "Ecology: Cultural and NonCultural" dalam James H. Clifton, ed. Introduction to Cultural Anthropology. Boston: Houghton Mifflin.

Runes, Dagobert D. (1963): Dictionary of Philoshophy. New Jersey: Littlefield, Adams\&Co

Sardar, Ziauddin. (1987): Masa Depan Islam. Bandung: Pustaka Salman.

Tilaar, A.R. (1994): Manajemen Pendidikan Nasional: Kajian Pendidikan Masa Depan. Bandung: Remaja Rosada Karya.

Yacob, Teuku. (1994): Islam, Pengetahuan dan Teknologi. Bandung: Mizan. 